satisfaction of knowing that the medicine supplied to his patient would be the same, wherever it was dispensed.

The Committee which was appointed to advise the Pharmacopœia Commission on the standardization of tablets has not as yet reached conclusions. Its report states that the possibility of defining tablets in the "British Pharmacopœia" has been explored and the general principles to be adopted have been worked out, but while good progress has been made towards the establishment of standards for composition, size and weight of a range of tablets in frequent use and the question of a test for disintegration has been investigated, further research is necessary before definite recommendations can be made. It is hoped, and expected, that an acceptable test for the rate of disintegration of tablets will be forthcoming before the next "Pharmacopœia" goes to press ; the need for one was clearly shown in papers read at the last meeting of the British Pharmaceutical Conference.

A curious recommendation is made to the Pharmacopoia Commission by the Committee on Pharmacy and Pharmacognosy as a test for the pungeney of tincture of capsicum. It is that 3 millilitres of a solution of stated dilution "swallowed all at once produces a distinct sensation of pungency in the throats of at least two out of three individuals". Possibly the criticism will be made that this is more like a test for throats than a test for capsicum.

\title{
PETROLOGY OF EAST GREENLAND
}

\author{
By DR. L. HAwKeS \\ BEDFord College, LONDON
}

$\mathrm{T}$ HIRTY years ago it might have been thought that the main forms of intrusive bodies in the North Atlantic Tertiary volcanic province were known. Then came the discovery by the Geological Survey of the cone-sheet and ring-dyke complexes, and now in a part of East Greenland very difficult of access Mr. L. R. Wager has had the good fortune to find, and, in association with Dr. W. A. Deer, the pluck and persistence to investigate, an intrusive mass which in form, composition and internal structure is unlike any hitherto known in the province. The work in the field and laboratory has been very thorough, and the results are now presented in a handsomely produced memoir which will be of absorbing interest to students of igneous rocks and doubtless a basis of lively discussion among them*.

The Skaergaard intrusive is finely exposed in a mountainous region, but as is so commonly the case with large intrusives, the original rock cover has been removed by erosion and the base is not seen. The mass narrows downwards and the 2,700 metres of its exposed thickness is interpreted as the upper part of an inverted cone some seven kilometres in diameter at its base and tilted $40^{\circ}$ from the vertical-it belongs to the class of 'funnel intrusions'. The pre-existing rock displaced by the intrusion must have been forced upwards, and that without appreciable disturbance of the neighbouring rock. The authors suggest that the expulsion of this huge mass was a sudden act, and that the cover was shattered by expanding gases and strewn far and wide. Rather mysterious is the way in which an extensive gabbro sill, believed to have been enclosed within the cover, has become disembodied, to lie within the intrusive. Whatever the mechanism of emplacement, there came into being within the upper part of the earth's crust a volume of magma enclosed - to use Prof. Tilley's apt phrase in a gigantie natural closed crucible, and the cooling of this perhaps unusually fluid melt proceeding under tranquil conditions has provided a remarkable demonstration of the course of differentiation in a basic magma.

Solidification first took place at the sides and top of the 'crucible' and then, more slowly, crystallization

* Geological Investigations in East Greenland, Part 3. The Petrology of the Skaergaard Intrusion, Kangerdlugssuag, East Greenland. B. continued in the main mass within to give a series of rock layers likened to a pile of saucers, many of the layers being distinguished by a preponderance of dark minerals at their bases. This layering is so prominent that on first seeing the Skaergaard region from a ship, Mr. Wager surmised the rocks to be massively bedded sandstones. Any hypothesis of successive intrusion seems to be ruled out, and the solid mass is believed to have grown from below upwards, largely by accumulation of crystals carried down by convection currents. This postulated upward course of solidification is strongly supported by the nature of the minerals : with increasing height in the intrusive, the olivines, pyroxenes and felspars show a gradual passage from higher to lower temperature species.

The original magma, as deduced from the chilled border rocks, was of basaltic composition, and very little change in silica content is shown by the majority of the successive rocks formed, but they become unusually rich in ferrous iron, and ferro-gabbros are described composed essentially of pyroxene, plagioclase, fayalite and some quartz. Then finally and abruptly a relatively small amount of acid granophyre resulted. Notwithstanding the extreme rarity in the earth's crust of rocks of ferro-gabbro composition, the authors hold that the course of differentiation here followed is the normal one for a basic magma. But the 'crucible' was not a platinum one. Its lower part was of acid gneiss, and the magma has reacted with inclusions of granophyre. These inclusions are considered to be altered gneiss, although - somewhat strangely perhaps-the passage of gneiss to granophyre seems not to have been observed either in the wall rocks or in the inclusions. To this 'contamination' of the magma the emergence of part at least of the final acid granophyre differentiate is ascribed, and the authors subseribe to the view, now steadily gaining ground, that the normal calc-alkaline series of igneous rocks is not derived from the straightforward differentiation of a basic magma but results from the incorporation within that magma of acidic material. If this is accepted, the large granophyre intrusions of Skye and elsewhere in the province must owe their origin to the fusion of acid gneiss or crustal sialic rocks of like composition : this, however, is still a controversial matter. 